\title{
Protein Intake, Especially Vegetable Protein Intake, Is Associated with Higher Skeletal Muscle Mass in Elderly Patients with Type 2 Diabetes
}

\author{
Akane Miki, Yoshitaka Hashimoto, Shinobu Matsumoto, Emi Ushigome, Takuya Fukuda, \\ Takafumi Sennmaru, Muhei Tanaka, Masahiro Yamazaki, and Michiaki Fukui
}

Department of Endocrinology and Metabolism, Kyoto Prefectural University of Medicine Graduate School of Medical Science, Kyoto, Japan

Correspondence should be addressed to Michiaki Fukui; sayarinapm@hotmail.com

Received 26 June 2017; Revised 20 September 2017; Accepted 4 October 2017; Published 25 October 2017

Academic Editor: Bernard Portha

Copyright (C) 2017 Akane Miki et al. This is an open access article distributed under the Creative Commons Attribution License, which permits unrestricted use, distribution, and reproduction in any medium, provided the original work is properly cited.

\begin{abstract}
Background/Aims. Protein intake is important for maintaining muscle mass in general population. However, it remains to be elucidated the association between dietary protein intake and skeletal muscle mass in elderly patients with type 2 diabetes. Methods. In this cross-sectional study of 168 elderly patients with type 2 diabetes, we investigated the relationship between skeletal muscle index (SMI) and protein intake. Bioimpedance analysis was used for measurement for skeletal muscle mass (kg) and SMI (\%), which was defined as skeletal muscle mass $(\mathrm{kg}) /$ total body weight $(\mathrm{kg}) \times 100$. Habitual food and nutrient intake were estimated by a questionnaire. Results. Protein intake was independently correlated with SMI after adjusting for age, hemoglobin A1c, C-peptide index, exercise, smoking, insulin treatment, total energy intake, and C-reactive protein (standardized regression coefficient $=0.664, P<0.001$ in men and standardized regression coefficient $=0.516, P=0.005$ in women). Additionally, the animal protein to vegetable protein ratio was negatively correlated with SMI after adjusting for covariates in men (standardized regression coefficient $=-0.339, P=0.005$ ). Conclusions. We found that total protein intake, especially vegetable protein intake, was positively associated with skeletal muscle mass in elderly patients with type 2 diabetes.
\end{abstract}

\section{Introduction}

The number of elderly patients with diabetes is increasing, and they are often accompanied by sarcopenia, which is known as the age-associated change of skeletal muscle, such as a loss of muscle mass, power, and function $[1,2]$. Recent studies revealed that sarcopenia is a risk of cardiovascular disease and mortality [3]. Thus, prevention of sarcopenia is an important issue for elderly patients with diabetes.

Sarcopenia is associated with an inadequate protein intake [4]: a low intake of dietary protein has been associated with a loss of muscle mass [5], and protein intake has been inversely associated with loss of muscle mass [6]. Previous studies suggested that relatively higher protein intake (over $1.2 \mathrm{~g} / \mathrm{kg}$ body weight (BW)/day) was associated with greater muscle strength and quality than lower intakes [7]. In addition, it has been recommended that $1.0-1.2 \mathrm{~g} / \mathrm{kg}$
BW/day of dietary protein intake for adults aged $\geq 65$ years should be consumed to keep and regain muscle mass and function [8].

On the other hand, diabetes accelerates the reduction of muscle mass and strength by hyperglycemia, insulin resistance, inflammatory cytokines, and endocrine changes [9]. Reduced insulin signaling leads to decreased protein synthesis and increased protein degradation, which can ultimately lead to reduced muscle mass [1] and insulin resistance causes muscle wasting [10]. Therefore, there is the possibility that the association between dietary protein intake and skeletal muscle mass is different in elderly patients with type 2 diabetes from that in general elderly population. However, it remains to be elucidated the association between dietary protein intake and skeletal muscle mass in elderly patients with type 2 diabetes. Thus, we investigated the association between dietary protein intake 


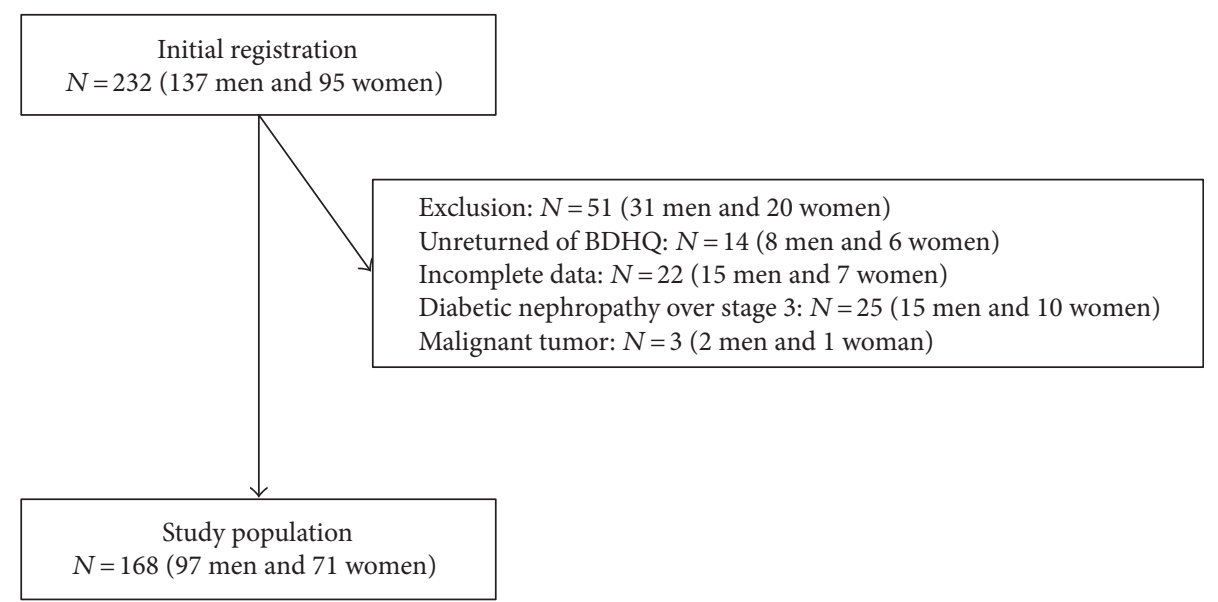

FIgURE 1: Inclusion and exclusion flow chart. BDHQ: brief-type self-administered diet history questionnaire.

and skeletal muscle mass in this cross-sectional study of elderly patients with type 2 diabetes.

\section{Material and Methods}

2.1. Study Patients. We performed a cross-sectional study in elderly patients with type 2 diabetes who were recruited from the outpatient clinic at the Kyoto Prefectural University of Medicine from August 2015 to April 2016. We included type 2 diabetes patients of age $\geq 65$ years and without physical inactivity. We excluded the patients with diabetic nephropathy stage 3 or more [11], inflammatory disease, malignancy, and endocrine disease [12]. In addition, we also excluded the patients who did not perform a brief-type selfadministered diet history questionnaire (BDHQ). Finally, approval for the study was obtained from the local research ethics committee, and written informed consent was obtained from all patients.

2.2. Estimation and Assessment of Habitual Food and Nutrient Intake. In this study, we used the BDHQ for the assessment of habitual food and nutrient intake [13]. BDHQ estimates the dietary intake of 58 food item situation of the past 1 month. BDHQ evaluates dietary habits during the preceding month and consists of the following five sections: (i) intake frequency of forty-six food and nonalcoholic beverage items; (ii) daily intake of rice, including type of rice, and miso soup; (iii) frequency of drinking alcoholic beverages and amount per drink for five alcoholic beverages; (iv) usual cooking methods; and (v) general dietary behavior [13]. Estimates of the intake of the 58 food items and the intakes of energy, protein, fat, and carbohydrate were calculated using an ad hoc computer algorithm for the BDHQ which was based on the Standard Tables of Food Composition in Japan [Standard Tables of Food Composition in Japan. Tokyo: Ministry of Education, Culture, Sports, Science and Technology; 2010 (in Japanese)]. The validity of BDHQ for the assessment of habitual food and nutrient intake was confirmed previously [13, 14]. Using BDHQ and the nutritional value calculation program, we estimated dietary total energy (kcal/day), carbohydrate (g/day), total protein (g/day), fat (g/day), and alcohol (g/day) intake. Protein from fish and shellfish, meat, eggs, and dairy products was included in animal protein [15]. Protein from cereals, pulses, potatoes, confectionaries, fruits, vegetables, alcoholic beverages, and nonalcoholic beverages was included in plant protein [15]. Protein intake (g/kg BW/day), animal protein intake (g/kg BW/day), and vegetable protein intake $(\mathrm{g} / \mathrm{kg} \mathrm{BW} /$ day) were calculated where each protein intake was divided by body weight $(\mathrm{kg})$ [8]. The animal protein to vegetable protein ratio was calculated as animal protein intake (g/day) divided by vegetable protein intake (g/day). In this study, none of the participants reported extremely low (under $600 \mathrm{kcal}$ ) or high (over $4000 \mathrm{kcal})$ energy intake [16].

2.3. Measurement of Body Composition Determined by Bioelectric Impedance. Body composition of participants was evaluated by the InBody 720 (InBody Japan, Tokyo, Japan), a multifrequency impedance body composition analyzer [17]. A multifrequency impedance body composition analyzer has good correlation with the dual-energy X-ray absorptiometry method and was also validated [18]. We obtained readings for body weight $(\mathrm{BW}, \mathrm{kg})$, skeletal muscle mass (SMM, kg), and body fat mass (kg). Skeletal muscle index (SMI, \%) was expressed as percent, dividing the SMM $(\mathrm{kg})$ by total body weight $(\mathrm{kg})[17,19,20]$.

2.4. Standardized Questionnaire for Lifestyle Factors. A standardized questionnaire was performed to all patients. Smoking status was categorized into two groups (nonsmoker or smoker). On the questionnaire, patients reported the kind and frequency of their participation in sports or recreational activities [20]. When participants performed any kind of sport regularly at least once a week, we categorized them as regular exercisers [21].

2.5. Data Collection. Body mass index (BMI) was defined as weight in kilograms divided by height in meter squared. After an overnight fast, venous blood was collected for the measurement of the levels of various factors, including fasting plasma glucose, total cholesterol, triglycerides, 
TABLE 1: Clinical characteristics of study patients.

\begin{tabular}{|c|c|c|}
\hline & $\begin{array}{c}\text { Men } \\
(n=97)\end{array}$ & $\begin{array}{l}\text { Women } \\
(n=71)\end{array}$ \\
\hline Age (year) & $72.9(6.0)$ & $73.0(5.2)$ \\
\hline Body weight $(\mathrm{kg})$ & $62.7(9.1)$ & $55.0(9.5)$ \\
\hline Body mass index $\left(\mathrm{kg} / \mathrm{m}^{2}\right)$ & $22.9(3.1)$ & $23.6(4.1)$ \\
\hline Skeletal muscle mass (kg) & $25.5(3.3)$ & $19.1(2.3)$ \\
\hline Skeletal muscle index (\%) & $41.0(3.7)$ & $35.1(4.1)$ \\
\hline Body fat mass $(\mathrm{kg})$ & $15.8(5.7)$ & $18.9(7.2)$ \\
\hline Smoking $(-/+)$ & $25 / 72$ & $60 / 11$ \\
\hline Regular exerciser $(-/+)$ & $64 / 33$ & $64 / 7$ \\
\hline Disease duration (year) & $16.6(9.3)$ & $15.9(9.9)$ \\
\hline Fasting plasma glucose $(\mathrm{mmol} / \mathrm{L})$ & $8.0(2.6)$ & $8.0(2.7)$ \\
\hline Hemoglobin A1c (\%) & $7.1(1.1)$ & $7.2(0.9)$ \\
\hline Hemoglobin Alc (mmol/mol) & $54(12)$ & $55(10)$ \\
\hline Creatinine $(\mu \mathrm{mol} / \mathrm{L})$ & $73.8(19.8)$ & $54.2(11.9)$ \\
\hline eGFR $\left(\mathrm{mL} / \mathrm{min} / 1.73 \mathrm{~m}^{2}\right)$ & $71.9(16.7)$ & $75.3(17.5)$ \\
\hline $\begin{array}{l}\text { Urine albumin } \\
\text { excretion ( } \mathrm{mg} / \mathrm{g} \text { creatinine) }\end{array}$ & $37.3(53.1)$ & $48.5(57.5)$ \\
\hline C-peptide (nmol/L) & $0.7(0.4)$ & $0.6(0.4)$ \\
\hline C-peptide index & $1.6(1.1)$ & $1.4(0.9)$ \\
\hline C-reactive protein $(\mu \mathrm{g} / \mathrm{L})$ & $\begin{array}{c}1307.2 \\
(2584.0)\end{array}$ & $\begin{array}{c}1612.7 \\
(4734.8)\end{array}$ \\
\hline Triglycerides (mmol/L) & $1.4(0.8)$ & $1.3(0.7)$ \\
\hline Total cholesterol (mmol/L) & $4.6(0.7)$ & $5.0(0.9)$ \\
\hline HDL cholesterol (mmol/L) & $1.4(0.4)$ & $1.7(0.4)$ \\
\hline Insulin treatment $(-/+)$ & $73 / 24$ & $53 / 18$ \\
\hline Energy intake (kcal) & $1941.3(568.9)$ & $1575.9(474.6)$ \\
\hline Protein intake (g/day) & $82.1(30.5)$ & $70.9(29.0)$ \\
\hline Protein intake (g/kg BW/day) & $1.3(0.5)$ & $1.3(0.6)$ \\
\hline $\begin{array}{l}\text { Animal protein } \\
\text { intake (g/kg BW/day) }\end{array}$ & $0.8(0.4)$ & $0.8(0.5)$ \\
\hline $\begin{array}{l}\text { Vegetable protein } \\
\text { intake (g/kg BW/day) }\end{array}$ & $0.5(0.2)$ & $0.5(0.2)$ \\
\hline $\begin{array}{l}\text { Animal protein to vegetable } \\
\text { protein ratio }\end{array}$ & $1.7(0.7)$ & $1.7(0.7)$ \\
\hline Fat intake (g/day) & $57.8(22.2)$ & $49.4(19.4)$ \\
\hline Carbohydrate intake (g/day) & $248.8(73.8)$ & $205.3(62.5)$ \\
\hline Alcohol intake (g/day) & $10.9(19.6)$ & $2.0(7.2)$ \\
\hline
\end{tabular}

Data was expressed as mean (SD) or number. eGFR: estimated glomerular filtration rate; HDL: high-density lipoprotein; BW: body weight.

high-density lipoprotein (HDL) cholesterol, C-reactive protein (CRP), C-peptide, uric acid, and creatinine. Hemoglobin Alc was assayed using high-performance liquid chromatography and was expressed as a National Glycohemoglobin Standardization Program unit. Glomerular filtration rate (GFR) was estimated using the Japanese Society of Nephrology equation: estimated GFR (eGFR) $(\mathrm{mL} / \mathrm{min} /$ $\left.1.73 \mathrm{~m}^{2}\right)=194 \times$ serum creatinine ${ }^{-1.094} \times$ age $^{-0.287}(\times 0.739$ for women) [22]. Urinary albumin and creatinine concentrations were determined using early morning spot urine. A mean value for urine albumin excretion was determined from three urine collections. C-peptide index was calculated as fasting serum C-peptide $(\mathrm{ng} / \mathrm{ml}) \times 100 /$ fasting plasma glucose $(\mathrm{mg} / \mathrm{dL})$ [23].

2.6. Statistical Analysis. JMP version 12.0 software (SAS Institute Inc., Cary, North Carolina) was used for statistical analyses and $P$ value $<0.05$ was considered statistically significant. Mean or frequencies of potential confounding variables were calculated. Continuous variables were presented as the mean \pm standard deviation (SD). Student's $t$-test for continuous variables or the chi-square test for categorical variables was performed to assess statistical significance of differences between groups. The relationship between SMI and dietary protein intake as well as the relationship between SMI and age or other variables was evaluated by Spearman's correlation analyses. To examine the effects of various factors on SMI, the following factors were considered simultaneously as independent variables for multiple regression analysis: age, hemoglobin A1c, C-peptide index, regular exercise, smoking, insulin treatment, energy intake, CRP, protein intake (g/kg BW/day), animal protein (g/kg BW/day), vegetable protein intake $(\mathrm{g} / \mathrm{kg} \mathrm{BW} /$ day), and the animal protein to vegetable protein ratio.

\section{Results}

In this study, 232 elderly patients (137 men and 95 women) with type 2 diabetes received BDHQ. Among them, a total of 218 patients completed the questionnaire (129 men and 89 women), yielding a collection rate of $94.0 \%$. We excluded 22 patients ( 15 men and 7 women) with incomplete data of covariates, 25 patients ( 15 men and 10 women) with diabetic nephropathy stage 3 or more, and 3 patients $(2$ men and 1 woman) with malignant tumor. Finally, the study population was 168 patients (97 men and 71 women) (Figure 1). There were no patients with respiratory insufficiency symptom.

Clinical characteristics of 168 patients with type 2 diabetes are shown in Table 1. The average (SD) of age and $\mathrm{HbAlc}$ was 72.9 (6.0) years and 7.1 (1.1) \% in men and 73.0 (5.2) years and $7.2(0.9) \%$ in women. The average (SD) of SMM and SMI was 25.5 (3.3) $\mathrm{kg}$ and 41.0 (3.7) \% in men and $19.1(2.3) \mathrm{kg}$ and 35.1 (4.1) \% in women. In addition, the average (SD) of protein intake was $1.3(0.5) \mathrm{g} / \mathrm{kg} \mathrm{BW} /$ day in men and $1.3(0.6) \mathrm{g} / \mathrm{kg}$ BW/day in women.

Relationship between SMI and protein intake or the other variables is shown in Table 2. Protein intake (g/kg BW/day) was positively associated with SMI $(r=0.262, P=0.010$ in men and $r=0.295, P=0.013$ in women). Animal protein and vegetable protein intakes were also positively associated with SMI $(r=0.209, P=0.040, r=0.279$, and $P=0.019$ in men and $r=0.316, P=0.002, r=0.357$, and $P=0.002$ in women).

Multiple regression analyses on SMI are shown in Table 3. Protein intake (g/kg BW/day) was independently correlated with SMI (standardized regression coefficient $=0.664, P<0.001$ in men and standardized regression coefficient $=0.516, P=0.005$ in women). Both animal protein intake $(\mathrm{g} / \mathrm{kg} \mathrm{BW} /$ day) (standardized regression coefficient $=$ $0.410, P=0.003$ in men and standardized regression 
TABLE 2: Simple correlation on skeletal muscle index.

\begin{tabular}{|c|c|c|c|c|}
\hline & \multicolumn{2}{|c|}{ Men } & \multicolumn{2}{|c|}{ Women } \\
\hline & $r$ & $P$ & $r$ & $P$ \\
\hline Age (year) & -0.008 & 0.941 & -0.129 & 0.286 \\
\hline Disease duration (year) & 0.087 & 0.397 & 0.080 & 0.513 \\
\hline Fasting plasma glucose (mmol/L) & 0.144 & 0.158 & -0.048 & 0.693 \\
\hline Hemoglobin A1c (\%) & 0.021 & 0.838 & -0.191 & 0.112 \\
\hline C-reactive protein $(\mu \mathrm{g} / \mathrm{L})$ & -0.313 & 0.002 & -0.098 & 0.416 \\
\hline C-peptide (nmol/L) & -0.141 & 0.169 & -0.210 & 0.079 \\
\hline C-peptide index & -0.153 & 0.135 & -0.156 & 0.193 \\
\hline Energy intake (kcal/day) & 0.082 & 0.423 & 0.098 & 0.418 \\
\hline Protein intake (g/kg BW) & 0.262 & 0.010 & 0.295 & 0.013 \\
\hline Animal protein intake (g/kg BW/day) & 0.209 & 0.040 & 0.279 & 0.019 \\
\hline Vegetable protein intake (g/kg BW/day) & 0.316 & 0.002 & 0.357 & 0.002 \\
\hline Animal protein to vegetable protein ratio & -0.008 & 0.937 & 0.102 & 0.396 \\
\hline Alcohol intake (g/day) & 0.152 & 0.138 & 0.124 & 0.303 \\
\hline
\end{tabular}

BW: body weight.

coefficient $=0.437, P=0.007$ in women $)$ and vegetable protein intake $(\mathrm{g} / \mathrm{kg} \mathrm{BW} /$ day) (standardized regression coefficient $=$ $0.625, P=<0.001$ in men and standardized regression coefficient $=0.690, P=<0.001$ in women) were also associated with SMI. Additionally, the animal protein to vegetable protein ratio was negatively correlated with SMI after adjusting for covariates in men (standardized regression coefficient = $-0.339, P=0.005)$.

\section{Discussion}

In this study, we showed that dietary total protein intake was positively associated with SMI in elderly patients with type 2 diabetes. In addition, we also showed that the animal protein to vegetable protein ratio was negatively correlated with SMI in men.

Previous studies suggested that relatively high protein intake was needed to keep muscle strength and quality [7, 8 ]. The mechanism by which dietary protein affects the muscle is through the stimulation of muscle protein synthesis and/or suppression of protein breakdown by the absorbed amino acids consumed in the diet [24]. Essential amino acids are the main ones to stimulate protein synthesis. Essential amino acids, especially leucine, are potent stimulators of muscle protein synthesis $[25,26]$, through activation of mammalian target of rapamycin pathway [27]. In addition, L-glutamine (Glu) prevents excessive muscle damage during an intensive training period $[28,29]$, through reduction of p38 MAPK activity [30]. It has been reported that muscle protein synthesis by low-dose essential amino acids was decreased in elderly [31]. Leucine and L-glutamine are rich not in only animal protein but also in plant protein, including soybeans, peanuts, and lentils [32]. Thus, it is needed to intake a large amount of essential amino acids for elderly individuals.

On the other hand, diabetes accelerates the reduction of muscle mass and strength [9]. Reduced insulin signaling leads to reduced muscle mass [1], and insulin resistance induces muscle protein degradation [10]. Therefore, there is the possibility that the association between dietary protein intake and skeletal muscle mass in elderly patients with type 2 diabetes is different from that in the general elderly population. In this study, we found that protein intake (g/kg BW/day) was positively associated with SMI in elderly patients with type 2 diabetes who were at a high risk of sarcopenia.

Interestingly, the animal protein to vegetable protein ratio was negatively correlated with SMI in men. This result suggested that vegetable protein might be better than animal protein for maintaining muscle mass. One of the considerable reasons is the anti-inflammatory effects on plants [33]. It has been reported that phytochemicals had a protective effect for oxidative stress and inflammation [33]. Phytochemicals reduced inflammatory markers, such as tumor necrosis factor alpha- $\alpha$, interleukin-6, CRP, and nuclear factor kappa B [33]. In fact, CRP was positively associated with animal protein to vegetable protein ratio in men $(r=0.23$, $P=0.024$ by Spearman's correlation analyses) in this study. Moreover, we also performed multiple regression analysis for the animal protein to vegetable protein ratio on SMI adjusting for age, hemoglobin A1c, C-peptide index, regular exercise, smoking, insulin treatment, energy intake, CRP, protein intake (g/kg BW/day), and antioxidant nutrients, including vitamins $\mathrm{A}, \mathrm{C}$, and $\mathrm{E}$; carotenes; and cryptoxanthin. The standardized regression coefficient became weak, although the animal protein to vegetable protein ratio was inversely correlated with SMI in men (standardized regression coefficient $=-0.262, P=0.045$ ). This result means that the antioxidant nutrients are involved in the influence of vegetable protein on SMI. Taking these findings together, vegetable protein might be better than animal protein for maintaining muscle mass.

We also evaluate the effect of the protein intake on SMI by density method. The proportion of protein intake 
TABLE 3: Multiple regression analysis on skeletal muscle index.

\begin{tabular}{|c|c|c|c|c|c|c|c|c|c|c|}
\hline \multirow[b]{2}{*}{ Men } & $\begin{array}{l}\text { Model 1 } \\
\text { Standardized } \\
\text { regression } \\
\text { coefficient }\end{array}$ & \multirow[t]{2}{*}{$P$} & $\begin{array}{l}\text { Model 2 } \\
\text { Standardized } \\
\text { regression } \\
\text { coefficient }\end{array}$ & \multirow[t]{2}{*}{$P$} & \multicolumn{2}{|c|}{$\begin{array}{l}\text { Model } 3 \\
\text { Standardized } \\
\text { regression } \\
\text { coefficient }\end{array}$} & \multirow[t]{2}{*}{$P$} & \multicolumn{2}{|c|}{$\begin{array}{l}\text { Model } 4 \\
\text { Standardized } \\
\text { regression } \\
\text { coefficient }\end{array}$} & \multirow[t]{2}{*}{$P$} \\
\hline & & & & & & & & & & \\
\hline Age & -0.173 & 0.107 & -0.107 & 0.337 & -0.202 & & 0.057 & -0.230 & & 0.029 \\
\hline Hemoglobin A1c & 0.048 & 0.626 & 0.047 & 0.655 & 0.025 & & 0.796 & 0.020 & & 0.834 \\
\hline C-peptide index & -0.124 & 0.194 & -0.145 & 0.152 & -0.070 & & 0.460 & -0.080 & & 0.389 \\
\hline Regular exerciser & 0.138 & 0.146 & 0.133 & 0.186 & 0.176 & & 0.060 & 0.167 & & 0.071 \\
\hline Smoking & 0.070 & 0.485 & 0.080 & 0.448 & 0.083 & & 0.394 & 0.087 & & 0.369 \\
\hline Insulin treatment & -0.116 & 0.237 & -0.139 & 0.183 & -0.058 & & 0.549 & -0.048 & & 0.624 \\
\hline Energy intake & -0.366 & 0.009 & -0.157 & 0.220 & -0.357 & & 0.006 & -0.497 & & 0.001 \\
\hline C-reactive protein & -0.274 & 0.008 & -0.242 & 0.026 & -0.148 & & 0.121 & -0.258 & & 0.009 \\
\hline Protein intake & 0.664 & $<0.001$ & & & & - & & 0.949 & & $<0.001$ \\
\hline $\begin{array}{l}\text { Animal protein } \\
\text { intake }\end{array}$ & & & 0.410 & 0.003 & & - & & & - & \\
\hline $\begin{array}{l}\text { Vegetable protein } \\
\text { intake }\end{array}$ & & & & & 0.690 & & $<0.001$ & & - & \\
\hline $\begin{array}{l}\text { Animal protein to } \\
\text { vegetable protein } \\
\text { ratio }\end{array}$ & & & & & & - & & -0.339 & & 0.005 \\
\hline \multicolumn{11}{|l|}{ Women } \\
\hline Age & -0.292 & 0.013 & -0.278 & 0.018 & -0.278 & & 0.014 & -0.300 & & 0.010 \\
\hline Hemoglobin A1c & -0.143 & 0.209 & -0.159 & 0.161 & -0.154 & & 0.153 & -0.128 & & 0.257 \\
\hline C-peptide index & -0.126 & 0.289 & -0.123 & 0.306 & -0.135 & & 0.235 & -0.129 & & 0.274 \\
\hline Regular exerciser & 0.095 & 0.409 & 0.092 & 0.425 & -0.001 & & 0.994 & 0.074 & & 0.513 \\
\hline Smoking & 0.134 & 0.253 & 0.117 & 0.316 & 0.153 & & 0.174 & 0.155 & & 0.184 \\
\hline Insulin treatment & 0.065 & 0.584 & 0.083 & 0.479 & 0.114 & & 0.302 & 0.053 & & 0.649 \\
\hline Energy intake & -0.239 & 0.176 & -0.143 & 0.355 & -0.314 & & 0.060 & -0.354 & & 0.064 \\
\hline C-reactive protein & -0.150 & 0.203 & -0.147 & 0.212 & -0.152 & & 0.178 & -0.151 & & 0.193 \\
\hline Protein intake & 0.516 & 0.005 & & & & - & & 0.777 & & 0.002 \\
\hline $\begin{array}{l}\text { Animal protein } \\
\text { intake }\end{array}$ & & & 0.437 & 0.007 & & - & & & - & \\
\hline $\begin{array}{l}\text { Vegetable protein } \\
\text { intake }\end{array}$ & & & & & 0.625 & & $<0.001$ & & - & \\
\hline $\begin{array}{l}\text { Animal protein to } \\
\text { vegetable protein } \\
\text { ratio }\end{array}$ & & & & & & - & & -0.250 & & 0.128 \\
\hline
\end{tabular}

BW: body weight. Exercise was defined as nonregular exerciser (0) or regular exerciser (1), smoking status was defined as nonsmoker (0) or smoker (1), and medication for insulin was defined as without (0) or with (1).

(\% energy) was not correlated with SMI (standardized regression coefficient $=0.14, P=0.183$ in men and standardized regression coefficient $=0.08, P=0.529$ in women) after adjusting for covariates, which is different from that of protein intake $(\mathrm{g} / \mathrm{kg} \mathrm{BW})$. One of the possible reasons of this difference is that the number of study participants was small. Another reason is that the absolute amount of protein intake might be more important than the proportion of protein intake in the elderly whose energy intake is reduced [34].

This study has several considerable limitations. First, the accuracy of diet survey depends on the memorial power of patients, because all the dietary variables were obtained by the self-reported questionnaires. However, BDHQ was correlated with total energy and protein intake by the 16-dayweighed dietary record [13], although the validity of the BDHQ among the participants with type 2 diabetes has not been examined yet. Second, we were unable to include the intake of dietary supplements in calculating protein intake. However, the use of supplements containing mainly protein or amino acid is uncommon in Japanese [35], and any influence of supplements on protein intake was not so high [15]. Third, we were unable to estimate amino acid components; therefore, we were unable to evaluate the association between 
each amino acid intake and SMI in this study. Fourth, we analyzed body composition of participants using a multifrequency impedance body composition analyzer. The dualenergy X-ray absorptiometry is a gold standard test for evaluating SMM. However, a multifrequency impedance body composition analyzer has good correlation with the dual-energy X-ray absorptiometry method and was validated [18]. Fifth, this study was a cross-sectional design, which did not permit the determination of causality. Sixth, we used dichotomous value for exercise, because we did not have detailed data of exercise or physical activity. Lastly, we did not investigate the association between sarcopenia and protein intake, because we included the patients without physical inactivity.

\section{Conclusions}

In conclusion, we found that total protein intake, especially vegetable protein intake, was positively associated with SMI in elderly Japanese patients with type 2 diabetes. Further prospective studies are needed to better assess the relationship between sarcopenia and protein intake in patients with type 2 diabetes.

\section{Disclosure}

The sponsors were not involved in the study design; in the collection, analysis, and interpretation of data; in the writing of this manuscript; or in the decision to submit the article for publication. The authors, their immediate families, and any research foundations with which they are affiliated have not received any financial payments or other benefits from any commercial entity related to the subject of this article. The authors declare that although they are affiliated with a department that is supported financially by a pharmaceutical company, the authors received no current funding for this study and this does not alter their adherence to all the journal policies on sharing data and materials.

\section{Conflicts of Interest}

Masahiro Yamazaki received honoraria from AstraZeneca plc. Michiaki Fukui received fees for promotional materials from AstraZeneca plc., Astellas Pharma Inc., Nippon Boehringer Ingelheim Co. Ltd., Daiichi Sankyo Co. Ltd., Eli Lilly Japan K.K., Kyowa Hakko Kirin Company Ltd., Kissei Pharmaceutical Co. Ltd., MSD K.K., Mitsubishi Tanabe Pharma Corporation, Novo Nordisk Pharma Ltd., Sanwa Kagaku Kenkyusho Co. Ltd., Sanofi K.K., Ono Pharmaceutical Co. Ltd., and Takeda Pharmaceutical Co. Ltd.

\section{Authors' Contributions}

Akane Miki originated and designed the study, researched the data, and wrote the manuscript. Yoshitaka Hashimoto originated and designed the study, researched the data, and reviewed the manuscript. Shinobu Matsumoto, Emi Ushigome, Takuya Fukuda, Takafumi Sennmaru, Muhei Tanaka, and Masahiro Yamazaki researched the data and contributed to the discussion. Michiaki Fukui researched the data and reviewed and edited the manuscript. Michiaki Fukui is the guarantor of this work and, as such, had full access to all the data in the study and takes responsibility for the integrity of the data and the accuracy of the data analysis. All authors were involved in the writing of the manuscript and approved the final version of this article.

\section{References}

[1] H. Umegaki, "Sarcopenia and frailty in older patients with diabetes mellitus," Geriatrics \& Gerontology International, vol. 16, pp. 293-299, 2016.

[2] Y. Hashimoto, T. Fukuda, C. Oyabu et al., "Impact of low-carbohydrate diet on body composition: meta-analysis of randomized controlled studies," Obesity Reviews, vol. 17, pp. 499-509, 2016.

[3] S. O. Chin, S. Y. Rhee, S. Chon et al., "Sarcopenia is independently associated with cardiovascular disease in older Korean adults: the Korea National Health and Nutrition Examination Survey (KNHANES) from 2009," PLoS One, vol. 8, article e60119, 2013.

[4] W. J. Evans, G. Paolisso, A. M. Abbatecola et al., "Frailty and muscle metabolism dysregulation in the elderly," Biogerontology, vol. 11, pp. 527-536, 2010.

[5] D. K. Houston, B. J. Nicklas, J. Ding et al., "Dietary protein intake is associated with lean mass change in older, community-dwelling adults: the Health, Aging, and Body Composition (Health ABC) Study," The American Journal of Clinical Nutrition, vol. 87, pp. 150-155, 2008.

[6] J. M. Beasley, A. Z. LaCroix, M. L. Neuhouser et al., "Protein intake and incident frailty in the Women's Health Initiative observational study," Journal of the American Geriatrics Society, vol. 58, pp. 1063-1071, 2010.

[7] D. R. Moore, "Keeping older muscle "young" through dietary protein and physical activity," Advances in Nutrition, vol. 5, pp. 599S-607S, 2014.

[8] J. Bauer, G. Biolo, T. Cederholm et al., "Evidence-based recommendations for optimal dietary protein intake in older people: a position paper from the PROT-AGE Study Group," Journal of the American Medical Directors Association, vol. 14, pp. 542-559, 2013.

[9] J. E. Morley, T. K. Malmstrom, L. Rodriguez-Mañas, and A. J. Sinclair, "Frailty, sarcopenia and diabetes," Journal of the American Medical Directors Association, vol. 15, pp. 853859, 2014.

[10] X. Wang, Z. Hu, J. Hu, J. Du, and W. E. Mitch, "Insulin resistance accelerates muscle protein degradation: activation of the ubiquitin-proteasome pathway by defects in muscle cell signaling," Endocrinology, vol. 147, pp. 4160-4168, 2006.

[11] M. Haneda, K. Utsunomiya, D. Koya et al., "A new classification of diabetic nephropathy 2014: a report from joint committee on diabetic nephropathy," Journal of Diabetes Investigation, vol. 6, pp. 242-246, 2015.

[12] A. J. Cruz-Jentoft, J. P. Baeyens, J. M. Bauer et al., "European Working Group on Sarcopenia in Older People. Sarcopenia: European consensus on definition and diagnosis: report of the European Working Group on Sarcopenia in Older People," Age and Ageing, vol. 39, pp. 412-423, 2010.

[13] S. Kobayashi, K. Murakami, S. Sasaki et al., "Comparison of relative validity of food group intakes estimated by 
comprehensive and brief-type self-administered diet history questionnaires against 16 d dietary records in Japanese adults," Public Health Nutrition, vol. 14, pp. 1200-1211, 2011.

[14] S. Kobayashi, S. Honda, K. Murakami et al., "Both comprehensive and brief self-administered diet history questionnaires satisfactorily rank nutrient intakes in Japanese adults," Journal of Epidemiology, vol. 22, pp. 151-159, 2012.

[15] S. Kobayashi, K. Asakura, H. Suga, S. Sasaki, and Three-generation Study of Women on Diets and Health Study Group, "High protein intake is associated with low prevalence of frailty among old Japanese women: a multicenter crosssectional study," Nutrition Journal, vol. 12, p. 164, 2013.

[16] K. Murakami, S. Sasaki, Y. Takahashi et al., "Dietary glycemic index and load in relation to metabolic risk factors in Japanese female farmers with traditional dietary habits," The American Journal of Clinical Nutrition, vol. 83, pp. 1161-1169, 2006.

[17] Y. Hashimoto, T. Osaka, T. Fukuda, M. Tanaka, M. Yamazaki, and M. Fukui, "The relationship between hepatic steatosis and skeletal muscle mass index in men with type 2 diabetes," Endocrine Journal, vol. 63, pp. 877-884, 2016.

[18] M. Kim, S. Shinkai, H. Murayama, and S. Mori, "Comparison of segmental multifrequency bioelectrical impedance analysis with dual-energy X-ray absorptiometry for the assessment of body composition in a community-dwelling older population," Geriatrics \& Gerontology International, vol. 15, pp. 1013-1022, 2015.

[19] H. C. Hong, S. Y. Hwang, H. Y. Choi et al., "Relationship between sarcopenia and nonalcoholic fatty liver disease: the Korean Sarcopenic Obesity Study," Hepatology, vol. 59, pp. 1772-1778, 2014.

[20] T. Osaka, Y. Hashimoto, T. Fukuda, M. Tanaka, M. Yamazaki, and M. Fukui, "Relationship between skeletal muscle mass and hepatic fibrosis in patients with type 2 diabetes," Diabetes \& Metabolism, vol. 43, pp. 184-186, 2017.

[21] Y. Hashimoto, M. Hamaguchi, T. Kojima et al., "Modest alcohol consumption reduces the incidence of fatty liver in men: a population-based large-scale cohort study," Journal of Gastroenterology and Hepatology, vol. 30, pp. 546-552, 2015.

[22] S. Matsuo, E. Imai, M. Horio et al., "Revised equations for estimated GFR from serum creatinine in Japan," American Journal of Kidney Diseases, vol. 53, pp. 982-992, 2009.

[23] Y. Kondo, S. Satoh, J. Nagakura, M. Kimura, U. Nezu, and Y. Terauchi, "Defining criteria for the introduction of liraglutide using the glucagon stimulation test in patients with type 2 diabetes," Journal of Diabetes Investigation, vol. 4, pp. 571575, 2013.

[24] B. B. Rasmussen, R. R. Wolfe, and E. Volpi, "Oral and intravenously administered amino acids produce similar effects on muscle protein synthesis in the elderly," The Journal of Nutrition, Health \& Aging, vol. 6, pp. 358-362, 2002.

[25] J. I. Baum, I. Y. Kim, and R. R. Wolfe, "Protein consumption and the elderly: what is the optimal level of intake?," Nutrients, vol. 8, no. 6, p. 359, 2016.

[26] K. L. English, J. A. Mettler, J. B. Ellison et al., "Leucine partially protects muscle mass and function during bed rest in middleaged adults," The American Journal of Clinical Nutrition, vol. 103, pp. 465-473, 2016.

[27] C. Tsien, G. Davuluri, D. Singh et al., "Metabolic and molecular responses to leucine-enriched branched chain amino acid supplementation in the skeletal muscle of alcoholic cirrhosis," Hepatology, vol. 61, pp. 2018-2029, 2015.
[28] Z. Legault, N. Bagnall, and D. S. Kimmerly, "The influence of oral L-glutamine supplementation on muscle strength recovery and soreness following unilateral knee extension eccentric exercise," International Journal of Sport Nutrition and Exercise Metabolism, vol. 25, pp. 417-426, 2015.

[29] E. Sasaki, T. Umeda, I. Takahashi et al., "Effect of glutamine supplementation on neutrophil function in male judoists," Luminescence, vol. 28, pp. 442-449, 2013.

[30] M. Girven, H. F. Dugdale, D. J. Owens, D. C. Hughes, C. E. Stewart, and A. P. Sharples, "L-glutamine improves skeletal muscle cell differentiation and prevents myotube atrophy after cytokine (TNF- $\alpha$ ) stress via reduced p38 MAPK signal transduction," Journal of Cellular Physiology, vol. 231, pp. 27202732, 2016.

[31] R. Calvani, A. Miccheli, F. Landi et al., "Current nutritional recommendations and novel dietary strategies to manage sarcopenia," The Journal of Frailty \& Aging, vol. 2, pp. 3853, 2013.

[32] F. Landi, R. Calvani, M. Tosato et al., "Protein intake and muscle health in old age: from biological plausibility to clinical evidence," Nutrients, vol. 8, no. 5, p. 295, 2016.

[33] M. A. Islam, F. Alam, M. Solayman, M. I. Khalil, M. A. Kamal, and S. H. Gan, "Dietary phytochemicals: natural swords combating inflammation and oxidation-mediated degenerative diseases," Oxidative Medicine and Cellular Longevity, vol. 2016, Article ID 5137431, 25 pages, 2016.

[34] M. A. de van der Schueren, S. Lonterman-Monasch, W. M. van der Flier, M. H. Kramer, A. B. Maier, and M. Muller, "Malnutrition and risk of structural brain changes seen on magnetic resonance imaging in older adults," Journal of the American Geriatrics Society, vol. 64, pp. 2457-2463, 2016.

[35] T. Imai, M. Nakamura, F. Ando, and H. Shimokata, "Dietary supplement use by community-living population in Japan: data from the National Institute for Longevity Sciences Longitudinal Study of Aging (NILS-LSA)," Journal of Epidemiology, vol. 16, pp. 249-260, 2006. 


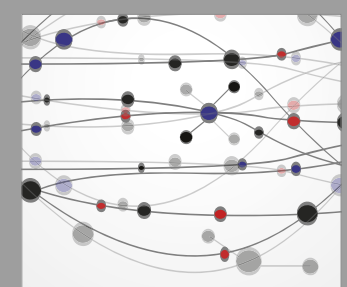

The Scientific World Journal
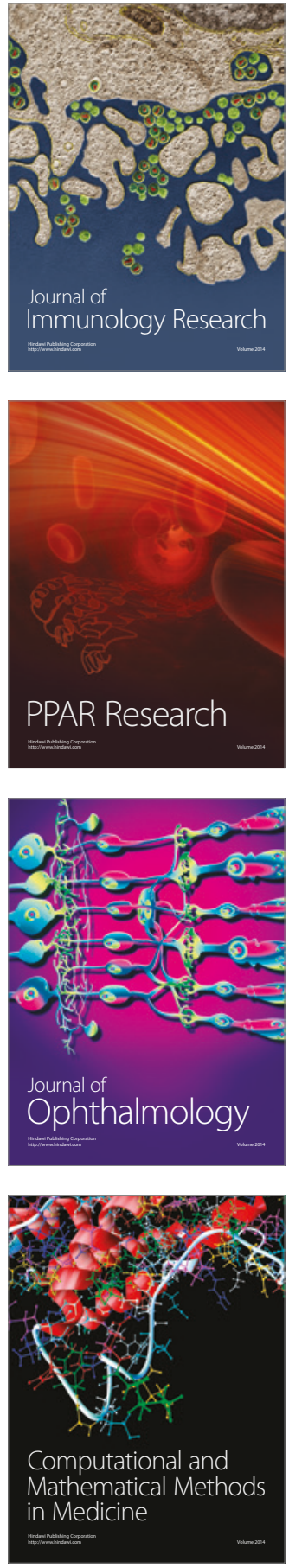

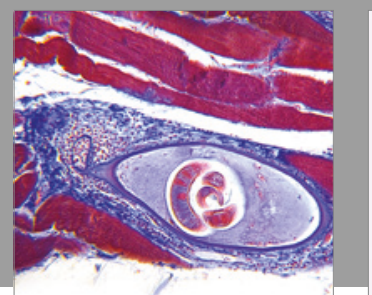

Gastroenterology Research and Practice
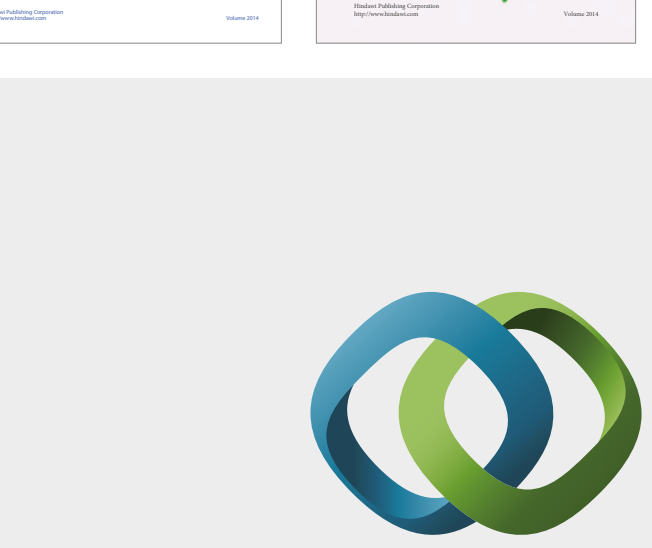

\section{Hindawi}

Submit your manuscripts at

https://www.hindawi.com
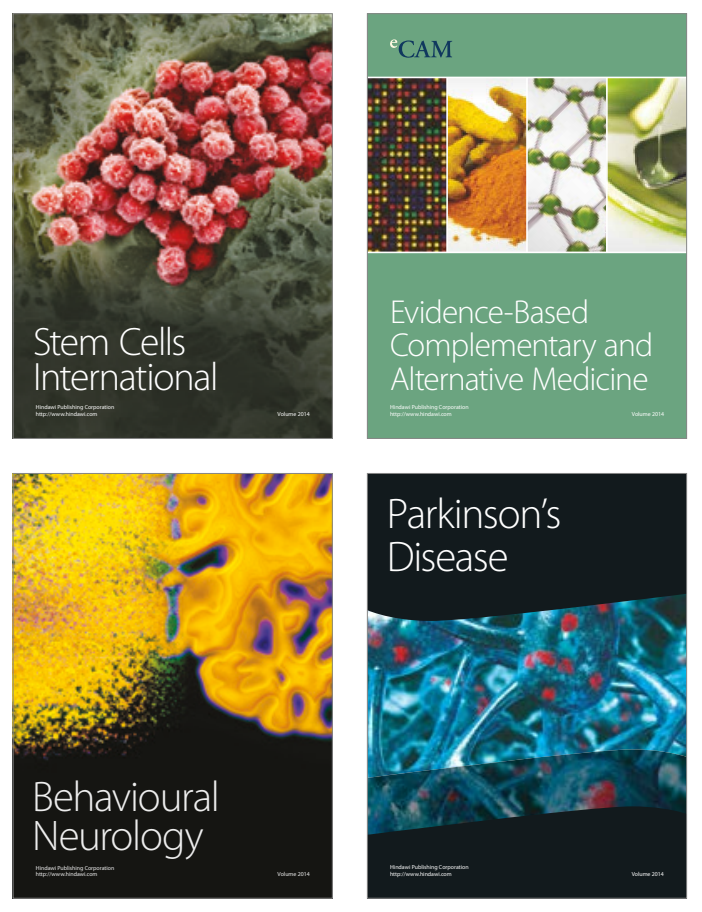
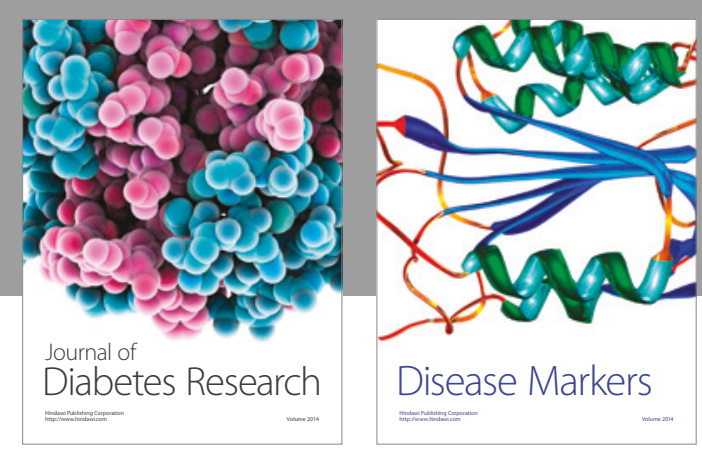

Disease Markers
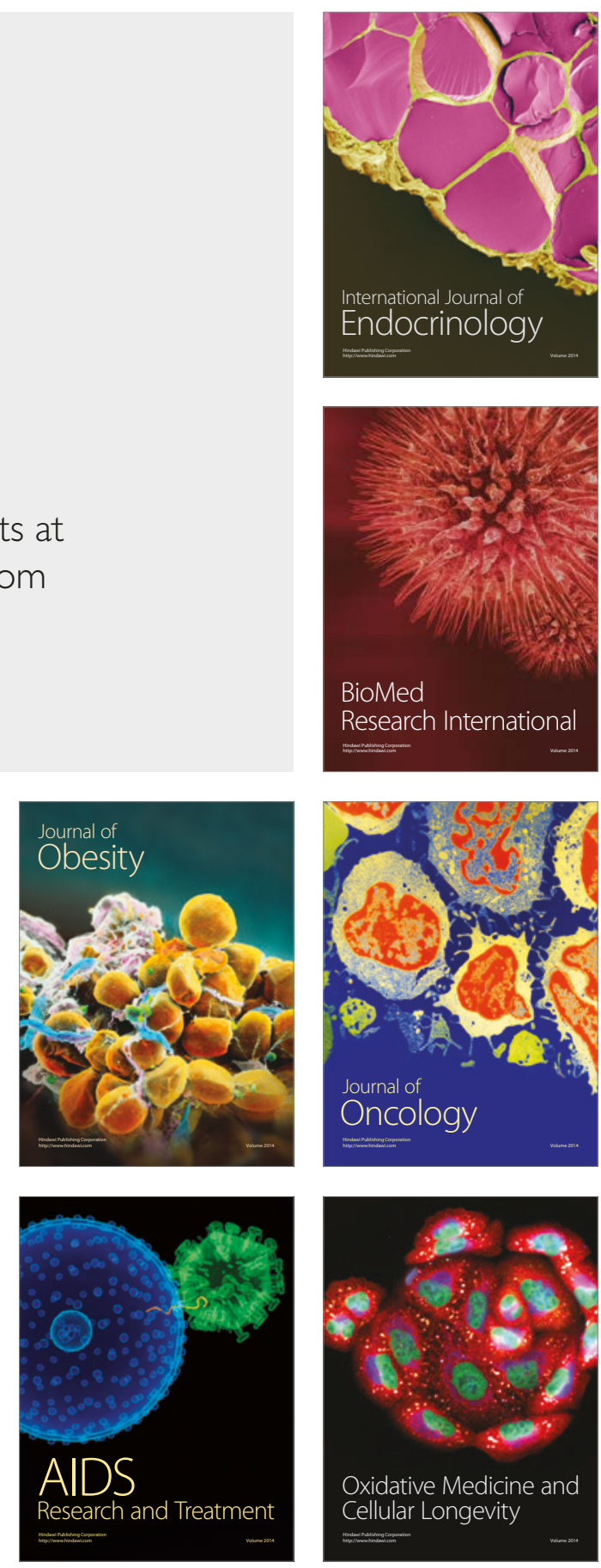